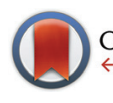

CrossMark \&lick for updates

Cite this: Dalton Trans., 2015, 44 16758

Received 3rd July 2015,

Accepted 26th August 2015

DOI: $10.1039 / \mathrm{c} 5 \mathrm{dt} 02542 \mathrm{~g}$

www.rsc.org/dalton

\title{
Structural diversity of bimetallic rhodium and iridium half sandwich dithiolato complexes $\uparrow$
}

\author{
Phillip S. Nejman, Brian Morton-Fernandez, David J. Moulding, \\ Kasun S. Athukorala Arachchige, David B. Cordes, Alexandra M. Z. Slawin, Petr Kilian \\ and J. Derek Woollins*
}

\begin{abstract}
The synthesis of a range of rhodium(III) and iridium(III) half sandwich complexes with aryl dithiolato ligands of varying geometry and flexibility are reported. These include dinuclear $\left[C p^{*} M(S-R-S)\right]_{2}$ complexes $3 b$ and $\mathbf{4 b}, \mathbf{M}=\mathrm{Rh}$, Ir; $\mathrm{S}-\mathrm{R}-\mathrm{S}=$ naphthalene-1,8-dithiolate $(\mathbf{b})$ and four dinuclear complexes bearing bridging dithiolate ligands $\left[\left(C p^{*} M\right)_{2}\left(\mu_{2}-C l\right)\left(\mu_{2}-S-R-S\right)\right] C l 3 c, 4 c, 5 b, 6 b, M=R h, I r ; S-R-S=$ naphthalene-1,8dithiolate (b) or acenaphthene-5,6-dithiolate (c). The introduction of a less rigid biphenyl dithiolate backbone resulted in the tetranuclear dicationic complex $\left[(C p * R h)_{4}(S-R-S)_{3}\right] C l_{2}(3 d), S-R-S=$ biphenyl-2,2'dithiolate (d) with dithiolate ligands in two different bridging modes. All new complexes were fully characterised by multinuclear NMR, IR, Raman and MS spectroscopy and single crystal X-ray diffraction.
\end{abstract}

\section{Introduction}

The coordination of $S, S$ bidentate ligands remains an important area of chemistry. Complexes bearing this type of ligand have a number of industrial applications including catalysts in vulcanisation $^{1,2}$ and lubricant additives. ${ }^{3}$ These complexes also show a range of electrochemical properties. ${ }^{4,5}$ In addition $S, S$ donors can support unusual magnetic properties ${ }^{6,7}$ and are important in biological systems. ${ }^{8}$ As part of our interest in the properties of sulfur donor systems we have investigated a series of dithiolate ligands containing polyaromatic backbones.

The coordination chemistry of these types of ligands has seen little study compared to other dithiolates such as benzene-1,2-dithiolate or ethane-1,2-dithiolate. The notable exceptions to this being a series of publications by Teo in the late 1970 s and early 1980 s on the oxidative addition of tetrathionaphthalene (TTN), tetrachlorotetrathionaphthalene (TCTTN) and tetrathiotetracene (TTT) (Fig. 1) to a variety of low valent metal centres. ${ }^{9-16}$

Compounds in which two metal centres are bridged by two sulfur atoms are of particular relevance to the work presented here as they give rise to $\mathrm{M}_{2} \mathrm{~S}_{2}$ centres. Examples of these include the tetra iron species $\left[\left\{(\mathrm{CO})_{3} \mathrm{Fe}\right\}_{2}(\mathrm{TTN})\left\{\mathrm{Fe}(\mathrm{CO})_{3}\right\}_{2}\right]$ and the polymeric nickel $\left[\left\{\mathrm{Ni}_{2}(\mathrm{TTN})\right]_{n}\right.$ and cobalt

University of St Andrews, EaStCHEM School of Chemistry, St Andrews, Fife, KY16 9ST, UK. E-mail:jdw3@st-and.ac.uk

$\dagger$ Electronic supplementary information (ESI) available. CCDC 1410515-1410521. For ESI and crystallographic data in CIF or other electronic format see DOI: 10.1039/c5dt02542g
$\left[\left\{(\mathrm{CO})_{2} \mathrm{Co}_{2}(\mathrm{TTN})\right]_{n}\right.$ systems. ${ }^{10}$ Another example of a complex bearing this type of ligand is the unusual trinuclear nickel(II) species $\left[\mathrm{Ni}_{3}\left(\mathrm{PPh}_{3}\right)_{3}\left(\mathrm{~S}_{2} \mathrm{C}_{10} \mathrm{Cl}_{6}\right)_{3}\right]$, which was obtained by the oxidative addition of hexachlorodithionaphthalene $(\mathrm{HCDTN})$ to $\left[\mathrm{Ni}(\operatorname{cod})_{2}\right](\operatorname{cod}=1,5$-cyclooctadiene) in the presence of triphenylphosphine. ${ }^{17}$ This trinuclear structure is in contrast to the mononuclear square planar compounds $\left[\mathrm{M}\left(\mathrm{PPh}_{3}\right)_{2}(\mathrm{HCDTN})\right](\mathrm{M}=\mathrm{Pd}$ or $\mathrm{Pt})$ obtained by reaction of $\left[\mathrm{Pd}\left(\mathrm{PPh}_{3}\right)_{3}\right]$ or $\left[\mathrm{Pt}\left(\mathrm{PPh}_{3}\right)_{4}\right]$ with the same ligand. ${ }^{17}$ There have also been examples of oligomeric, dimeric and monomeric zinc complexes with no co-ligands, with pyridine or with neocuproin, respectively, of sterically crowded and electron poor naphthalene-1,8-dithiolate derivatives. ${ }^{18}$

A number of complexes containing the 1,1'-binaphthalene2,2'-dithiolate ligand have been prepared from metathesis reactions, for example, by reaction of the dithiol with

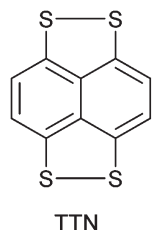<smiles></smiles>

TCTTN

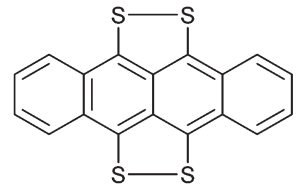

TTT<smiles>N#Cc1c(Cl)c(Cl)c2c(Cl)c(Cl)c(Cl)c3c2c1SS3</smiles>

Fig. 1 Structurally related naphthalene ligands. 
$[\mathrm{Rh}(\mu-\mathrm{OMe})(\mathrm{cod})]_{2}$ to give a dinuclear complex with a bridging disulfide ligand (Fig. 3). ${ }^{19}$ In many of these reactions the purpose has been to develop complexes for catalytic polymerisation reactions such as the regioselective hydroformylation of styrene. Complexes containing the ligand 4,4'-biphenanthrene$3,3^{\prime}$-dithiolate have also been shown to react with carbon monoxide to give interesting dinuclear tetracarbonyl complexes and with $\mathrm{PR}_{3}\left(\mathrm{R}=\mathrm{Ph}, \mathrm{C}_{6} \mathrm{H}_{11}, \mathrm{OC}_{6} \mathrm{H}_{4}(o-t \mathrm{Bu})\right)$ to give mixed ligand di- and tetranuclear complexes. ${ }^{20,21}$ Ruiz and coworkers have also produced a palladium dimer complex using the mixed thiol and thio-ether ligand. The dimer was shown to convert to a monomer on addition of triphenylphosphine. ${ }^{22}$ More recently there has been interest in using naphthalene1,8-dithiolate and 1,1'-biphenyl-2,2'-dithiolate iron complexes as electron transfer catalysts designed to mimic iron hydrogenases (Fig. 3). ${ }^{23-28}$

The coordination chemistry of the structurally related acenaphthene-5,6-dithiolate motif is less well documented with only one example of a complex incorporating this type of ligand out with our research. Topf and co-workers have used the acenaphthene backbone as a linker between a 1,2-diimine unit and a dithiolate binding site. ${ }^{29}$ The iron carbonyl complex bearing this ligand was shown to have potential as a multielectron transfer photosensitiser for artificial photosynthesis and as a bio-inspired photoredox catalyst. ${ }^{29}$ Apart from electron transfer mimics there has been little study on complexes bearing the 1,1'-biphenyl-2,2'-dithiolate ligand. A derivatised version of dibenzo[c,e]-1,2-dithiin has been bound to copper ${ }^{30}$ with a molybdenum complex also known. ${ }^{31,32}$

Herein we describe the synthesis of a series of rhodium(III) and iridium(III) half sandwich dithiolato complexes. The complexes have been characterised, principally by multinuclear NMR spectroscopy and single crystal X-ray diffraction. Tuning of the reaction conditions allowed investigation into the different binding modes of the dithiolate ligands.

\section{Results and discussion}

The diprotic proligands benzene-1,2-dithiol $\left(\mathbf{H}_{\mathbf{2}} \mathbf{a}\right)$, naphthalene-1,8-dithiol $\left(\mathbf{H}_{\mathbf{2}} \mathbf{b}\right)$, acenaphthene-5,6-dithiol $\left(\mathbf{H}_{\mathbf{2}} \mathbf{c}\right)$ and 1,1'biphenyl-2,2'-dithiol ( $\mathbf{H}_{\mathbf{2}} \mathbf{d}$ ) (Fig. 2) were prepared following literature procedures. ${ }^{33-37}$ The half sandwich complexes $\mathbf{1}$ and 2 were also prepared following literature procedures. ${ }^{38}$ The syntheses of complexes $\mathbf{3 a - d}$ and $\mathbf{4 a - c}$ are shown in Scheme 1. The metathesis of the chloride ligands in $\mathbf{1}$ and $\mathbf{2}$ with the

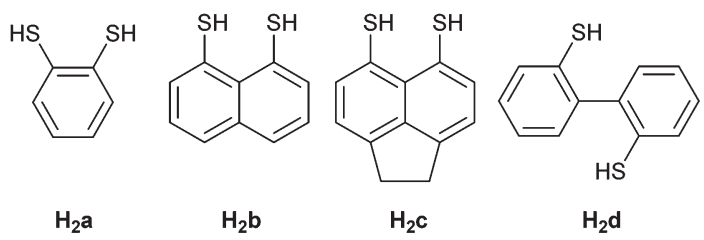

Fig. 2 Dithiol proligands studied in this work.
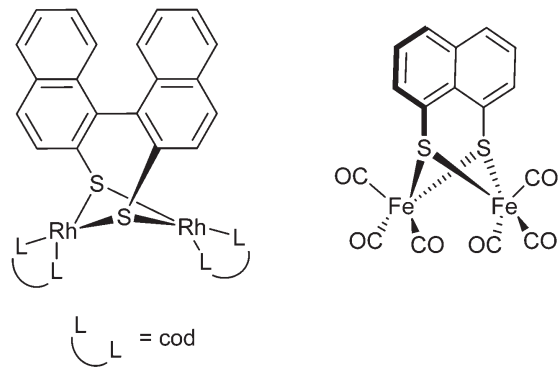

Fig. 3 Examples of catalysts bearing dithiolato ligands [asymmetric hydroformylation (left) and electron transfer catalyst (right)].

dithiolato ligands proceeds smoothly in refluxing THF with elimination of $\mathbf{H C l}$. New complexes $\mathbf{3 b} \mathbf{b}-\mathbf{d}$ and $\mathbf{4 b}$ were isolated in $40-84 \%$ yields. However, the iridium complex $4 \mathbf{c}$ was obtained in only a $2 \%$ yield using this method. Improved yields for the formation of $3 \mathbf{c}(83 \%)$ and $4 \mathbf{c}(98 \%)$ were obtained using a different method discussed below and outlined in Scheme 2. In all cases purification was performed by column chromatography on silica using either dichloromethane or a dichloromethane/methanol (or ethanol) mixture.

In the work by $\mathrm{Xi}$ and co-workers $3 \mathbf{a}$ and $\mathbf{4 a}$ were prepared by the addition of a methanol solution of 1 or 2 to a methanol solution containing $\mathbf{H}_{2}$ a and sodium methoxide at room temperature for 6 hours (3a) or 15 hours (4a). ${ }^{39}$ We found that heating $\mathbf{1}$ or $\mathbf{2}$ with proligand $\mathbf{H}_{2} \mathbf{a}$ in THF under reflux for 2 hours, followed by purification as above, resulted in comparable yields to those previously reported.

Since the ${ }^{1} \mathrm{H},{ }^{13} \mathrm{C}\left\{{ }^{1} \mathrm{H}\right\}$ NMR and structural data for $\mathbf{3 a}$ and 4a were reported earlier, we have limited our discussion to complexes 3b-d, 4b/c, 5b and $\mathbf{6 b}$. The ${ }^{1} \mathrm{H}$ NMR data $\left(\mathrm{CDCl}_{3}\right)$ for complexes $\mathbf{3 b}$ and $\mathbf{4 b}$ show the $\mathrm{Cp}^{*}$ signal shifted upfield $(\Delta \delta=0.45$ (3b), $0.36(\mathbf{4 b}) \mathrm{ppm})$ compared to precursors 1 and 2 , respectively, and six distinct aromatic signals from the naphthalene backbone (8.14-7.09 ppm). Both of these dimeric complexes proved to be stable in solution over a period of several days as the ${ }^{1} \mathrm{H}$ NMR spectrum showed no additional peaks which would correspond to the monomer after this time. This is in contrast to $\mathbf{3 a}$, which exists in both the mono and dimeric form in solution, and $\mathbf{4 a}$, which is a stable 16 electron species showing no dimeric form in solution. ${ }^{39}$ The ${ }^{13} \mathrm{C}\left\{{ }^{1} \mathrm{H}\right\}$ NMR data $\left(\mathrm{CDCl}_{3}\right)$ mirror the proton NMR spectra for $3 \mathbf{b}$ and $4 \mathbf{b}$ with ${ }^{1} J_{\mathrm{C}-\mathrm{Rh}}$ coupling $(5.7 \mathrm{~Hz})$ observed in complex $\mathbf{3 b}$ for the quaternary $\mathrm{Cp}^{*}$ carbons. APCI mass spectra show both the $[\mathrm{M}+\mathrm{H}]^{+}$and $\left[\frac{1}{2} \mathrm{M}+\mathrm{H}\right]^{+}$signals for the complexes $\mathbf{3 b}$ and $\mathbf{4 b}$, with purity of these two complexes confirmed by means of elemental analysis. Accurate elemental analysis was also obtained for $\mathbf{3 a}$ and $\mathbf{4 a}$ to show our synthetic method also resulted in pure material.

Despite the proligands $\mathbf{H}_{2} \mathbf{b}$ and $\mathbf{H}_{2} \mathbf{c}$ being closely related (both sterically and electronically), reactions with the latter gave complexes of different connectivity. Thus, the reaction of 1 or 2 with $\mathbf{H}_{2} \mathbf{c}$ produced a set of cationic complexes, $3 \mathbf{c}$ and 4c, where the dithiolate acts as a bridging ligand replacing two 


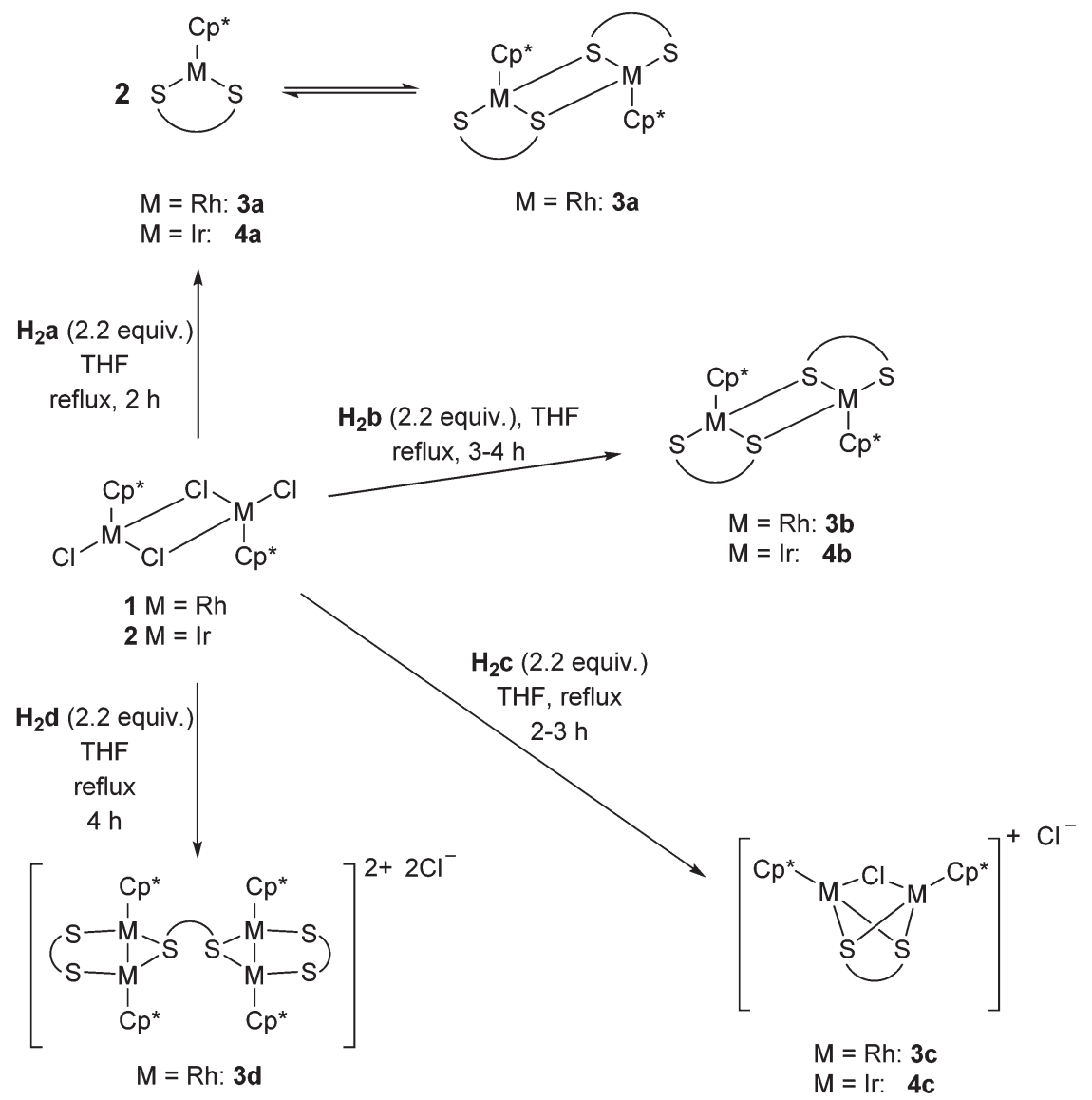

Scheme 1 Reaction scheme for the preparation of complexes $3 a-d$ and $4 a-c$.

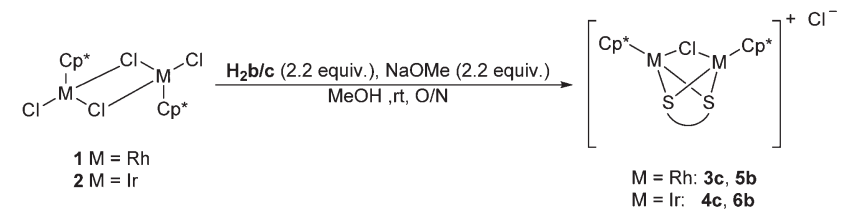

Scheme 2 Alternative reaction scheme for the preparation of $3 c$ and $4 c$ and the formation of $5 b$ and $6 b$.

of the chloride ligands. One bridging chloride remains whilst the final chloride acts as the counter ion. A similar outcome was observed when the biphenyl ligand $\left(\mathbf{H}_{\mathbf{2}} \mathbf{d}\right)$ was used, namely the tetranuclear complex $\mathbf{3 d}$. In this case the bridging chloride was replaced with another biphenyl ligand, which, due to its rotational flexibility allowed two of the binuclear moieties to be joined. The ${ }^{1} \mathrm{H}$ NMR data $\left(\mathrm{CDCl}_{3}\right)$ showed the expected upfield shift of the $\mathrm{Cp}^{*}$ signal, consistent with coordination of the thiolate ligand. For $3 \mathbf{d}$ two $\mathrm{Cp}^{*}$ signals $(2 \times$ $30 \mathrm{H})$ were observed which is likely due to the restricted rotation around the aryl-aryl bond of the bridging biphenyl ligand. The aromatic backbone of $3 \mathbf{c}$ and $\mathbf{4 c}$ showed two signals in the range of $8.37-7.31 \mathrm{ppm}$, whilst in $3 \mathrm{~d}$ multiplets were observed due to overlapping signals. The ${ }^{13} \mathrm{C}\left\{{ }^{1} \mathrm{H}\right\}$ NMR spectra of $3 \mathbf{c} / \mathbf{d}$ and $\mathbf{4 c}\left(\mathrm{CDCl}_{3}\right)$ again mirror the proton NMR spectra with marginally larger carbon-rhodium coupling observed $\left({ }^{1} J_{\mathrm{C}-\mathrm{Rh}}=6.5-7.4 \mathrm{~Hz}\right)$ for $3 \mathbf{c}$ and $3 \mathrm{~d}$ than in our previous complex $3 \mathbf{3 b}$. The $[\mathrm{M}-\mathrm{Cl}]^{+}(3 \mathbf{c}, 4 \mathbf{c})$ and $[\mathrm{M}-2 \mathrm{Cl}]^{2+}(\mathbf{3 d})$ fragments were observed in the ES mass spectra, purity was confirmed by elemental analysis for $\mathbf{3 c}$ and $\mathbf{4 c}$.

Given the similarity between proligands $\mathbf{H}_{2} \mathbf{b}$ and $\mathbf{H}_{2} \mathbf{c}$, further investigation into forming the dimeric analogues to $\mathbf{3} \mathbf{b}$ and $\mathbf{4 b}$ (with completely displaced $\mathrm{Cl}$ ligands) was performed. We followed the procedure employed by $\mathrm{Xi}$ and co-workers using sodium methoxide in methanol at room temperature, however, this still resulted in the formation of complexes 3c and $\mathbf{4 c}$ (Scheme 2). Further attempts at higher temperatures (refluxing for between 7 and 48 hours) were carried out to try and drive the reaction forward to the dimeric complex. In all cases the cationic complexes $3 \mathbf{c}$ and $\mathbf{4 c}$ were the only products observed by ${ }^{1} \mathrm{H}$ NMR spectroscopy. The conditions shown in Scheme 2 gave the highest yields for $3 \mathbf{c}$ and $\mathbf{4 c}$ of $83 \%$ and $98 \%$ respectively. In light of this attempts at selectively forming the complex containing a bridging dithiolate ligand were made with $\mathbf{H}_{2} \mathbf{b}$ (Scheme 2). From these reactions we isolated both $\mathbf{5 b}$ and the dimeric complex $\mathbf{3 b}$ in a $58 \%$ and $14 \%$ yield, respectively, as well as $\mathbf{6 b}(75 \%)$ and the dimeric complex $4 \mathbf{b}(7 \%)$. The ${ }^{1} \mathrm{H}$ and ${ }^{13} \mathrm{C}\left\{{ }^{1} \mathrm{H}\right\}$ NMR spectra of the new 
complexes $\mathbf{5 b}$ and $\mathbf{6 b}$ match the proposed structure with further confirmation obtained by means of elemental analysis and ES mass spectrometry.

\section{X-ray crystallography}

The crystal structures of complexes $\mathbf{3 b}-\mathbf{d}, \mathbf{4 b}-\mathbf{c}, \mathbf{5 b}$ and $\mathbf{6 b}$ are shown in Fig. 4 and 5 with selected structural parameters shown in Tables 1 and 2. The X-ray analyses show that in every example the metal centre adopts a piano stool geometry. Analysis of the single crystal structures of $\mathbf{5 b}$ and $\mathbf{6 b}$ (which are analogous to $\mathbf{3 b}$ and $\mathbf{4 b}$ ) is not included due to the disorder in the $\mathrm{Cp}^{*}$ rings/solvent. We include the data only to confirm the connectivity of the complexes.

In the case of $\mathbf{3} \mathbf{b}$ and $\mathbf{4} \mathbf{b}$ the coordination sphere of the metal is completed by $\mathrm{S} 1$ acting as a $\mu_{3}$-bridging atom resulting in a dimeric 18e complex. The M1-S1 bond lengths [3b

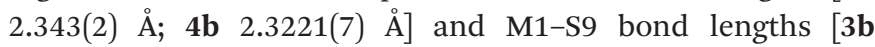

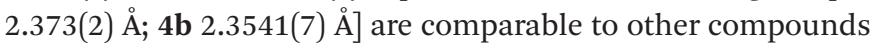
of this type. ${ }^{40-42}$ The M1-S1' bond length is marginally longer than the other $\mathbf{M}-\mathrm{S}$ bonds in both $\mathbf{3 b}$ and $\mathbf{4 b}$ as one of the sulfur atoms forms another dative bond. The M1-S1, M1-S9 and $\mathrm{M} 1-\mathrm{S} 1^{\prime}$ bond lengths in $\mathbf{3 b}$ and $\mathbf{4 b}$ are related to $\mathrm{M} 1^{\prime}-\mathrm{S} 1^{\prime}$, M1'-S9' and M1'-S1 through a crystallographically imposed centre of symmetry. The peri S...S distance has increased compared to the pro-ligand $\mathbf{H}_{2} \mathbf{b}[2.951(2) \AA]^{37}$ for $\mathbf{3 b}[3.264(3) \AA]$ and $\mathbf{4 b}[3.250(1) \AA]$ as the metal centre bridges the peri positions. All the non-Cp* angles around the metal centre are reduced to less than $90^{\circ}$ ranging from $79.40(7)^{\circ}-87.57(7)^{\circ}$ in 3b and $78.94(2)^{\circ}-88.05(2)^{\circ}$ in $\mathbf{4 b}$. This is a result of the naphthalene backbone restricting the position of the sulfur atoms meaning a more idealised geometry is unattainable. In this instance the splay angles are both large and positive [3 $\mathbf{b}$ $20.7(7)^{\circ}, 4 \mathbf{b} 21.4(2)^{\circ}$ ] showing the effect of the metal forcing the sulfur atoms apart. Both $\mathbf{3 b}$ and $\mathbf{4 b}$ have comparable S1-C1 $\cdots \mathrm{C} 9-\mathrm{S} 9$ torsion angles $\left(\approx 11^{\circ}\right)$ and show distinct buckling of the central naphthalene ring system.

The metal-sulfur bond lengths in the ionic complexes 3c $[2.3708(7)-2.3820(7) \AA]$ and 4c [2.383(1)-2.394(1) $\AA]$ are similar to other complexes bearing bridging dithiolate ligands. ${ }^{43}$ The bridging metal-chlorine bond lengths are slightly elongated compared to the starting complexes 1 and 2. ${ }^{44,45}$ All the non- $\mathrm{Cp}^{*}$ angles around the metal are reduced to
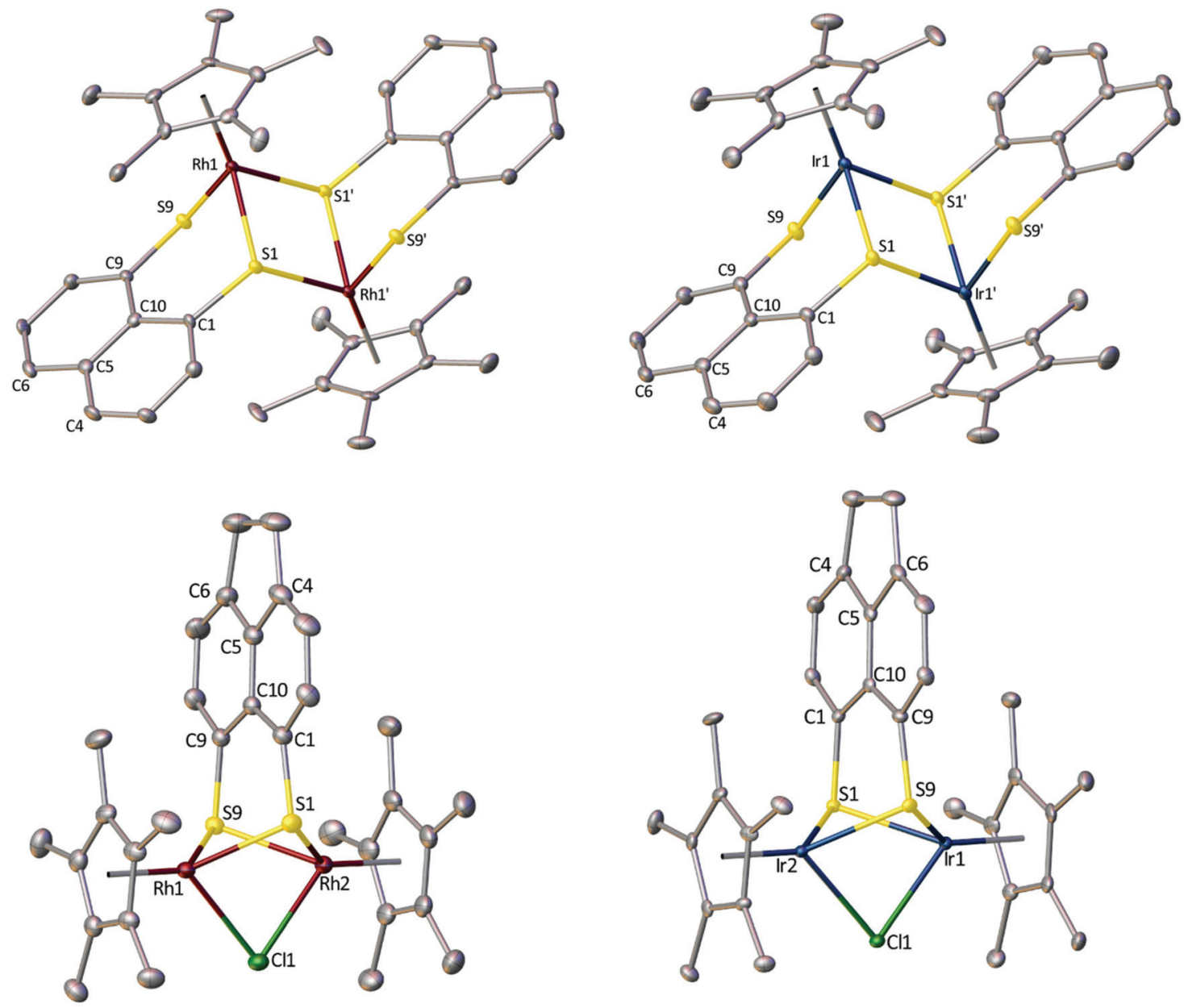

Fig. 4 Crystal structures of $3 b$ (Top left), 4b (Top right), 3c (Bottom left) and 4c (Bottom right). Water molecules and chloride counter ions from 3c and $4 \mathrm{c}$ are omitted for clarity. Hydrogen atoms are omitted from all structures for clarity. 


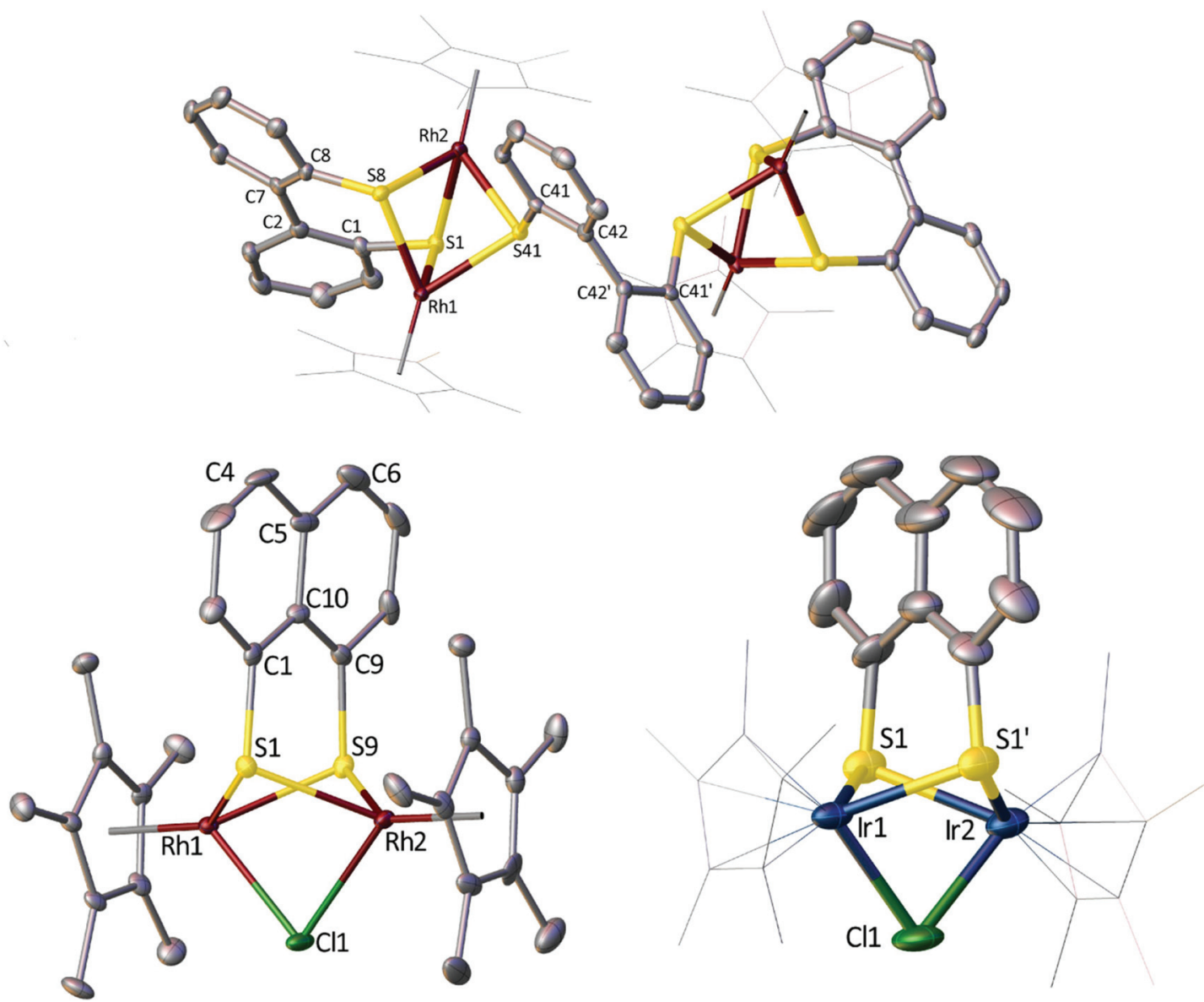

Fig. 5 Crystal structures of $3 d$ (Top), $5 b$ (Bottom left) and $6 b$ (Bottom right). The Cp* rings of $6 b$ have been wire framed for clarity. Solvent molecules and chloride counter ions from $5 b$ and $6 b$ are omitted for clarity. Hydrogen atoms are omitted from all structures for clarity.

Table 1 Selected bond lengths $[\AA \AA]$ and angles $\left[{ }^{\circ}\right]$ for complexes $3 b, 3 c$, $4 b$ and $4 c$

\begin{tabular}{lllll}
\hline & $3 \mathbf{b}$ & $3 \mathbf{c}$ & $\mathbf{4 b}$ & $\mathbf{4 c}$ \\
\hline M1-S1 & $2.343(2)$ & $2.3739(6)$ & $2.3221(7)$ & $2.3844(8)$ \\
M1-S9 & $2.373(2)$ & $2.3708(7)$ & $2.3541(7)$ & $2.3937(8)$ \\
M1-S1' & $2.425(2)$ & - & $2.3927(7)$ & - \\
M1-Cl1 & - & $2.4754(6)$ & - & $2.4790(8)$ \\
M2-S1 & - & $2.3820(7)$ & - & $2.3855(9)$ \\
M2-S9 & - & $2.3718(6)$ & - & $2.3864(7)$ \\
M2-Cl2 & - & $2.4786(7)$ & - & $2.4761(8)$ \\
S1-M1-S9 & $87.56(7)$ & $80.08(2)$ & $88.05(2)$ & $78.60(3)$ \\
S1-M1-S1' & $81.71(7)$ & - & $79.70(2)$ & - \\
S1-M1-Cl1 & - & $80.81(2)$ & - & $78.21(3)$ \\
S1-M2-S9 & - & $79.90(2)$ & - & $78.72(3)$ \\
S1-M2-Cl1 & - & $80.58(2)$ & - & $78.25(3)$ \\
S9-M1-S1' & $79.39(6)$ & - & $78.94(2)$ & - \\
S9-M1-Cl1 & - & $80.96(2)$ & - & $78.27(2)$ \\
S9-M2-Cl1 & - & $80.88(2)$ & - & $78.46(2)$ \\
Splay angle ${ }^{a}$ & $20.8(6)$ & $15.7(2)$ & $21.4(2)$ & $14.5(3)$ \\
S1-C1‥C9-S9 & $-11.3(4)$ & $2.7(1)$ & $-11.1(2)$ & $2.6(2)$ \\
C1-C10-C5-C6 & $179.9(6)$ & $178.4(2)$ & $179.4(3)$ & $179.8(3)$ \\
C9-C10-C5-C4 & $-175.4(6)$ & $179.1(2)$ & $175.1(3)$ & $178.4(3)$
\end{tabular}

${ }^{a}$ Splay angle $=[(\mathrm{S}(1)-\mathrm{C}(1)-\mathrm{C}(10))+(\mathrm{C}(1)-\mathrm{C}(10)-\mathrm{C}(9))+(\mathrm{C}(10)-\mathrm{C}(9)-\mathrm{S}(9))]$ -360 . less than $90^{\circ}\left[3 \mathbf{c} 79.90(7)-80.96(7)^{\circ}\right.$ and $\left.4 \mathbf{c} 78.17(4)-78.56(4)^{\circ}\right]$ and show less variation compared to $\mathbf{3 b}$ and $\mathbf{4 b}$. The splay angles are both positive, $3 \mathbf{c} 15.7(2)^{\circ}$; $4 \mathbf{c} 14.6(3)^{\circ}$, as the sulfur atoms bridge the two metal centres. Less strain on the back-

Table 2 Selected bond lengths $[\AA ̊]$ and angles $\left[^{\circ}\right]$ for complex 3d

\begin{tabular}{ll}
\hline & $3 \mathbf{d}$ \\
\hline M1-S1 & $2.366(2)$ \\
M1-S8 & $2.336(2)$ \\
M1-S41 & $2.466(2)$ \\
M2-S1 & $2.343(2)$ \\
M2-S8 & $2.383(2)$ \\
M2-S41 & $2.449(2)$ \\
S1-M1-S8 & $80.09(5)$ \\
S1-M1-S41 & $74.67(5)$ \\
S1-M2-S8 & $79.58(5)$ \\
S1-M2-S41 & $75.41(5)$ \\
S8-M1-S41 & $79.16(5)$ \\
S8-M2-S41 & $78.61(5)$ \\
C1-C2-C7-C8 & $-28(1)$ \\
C41-C42-C42'-C41' & $69.2(9)$
\end{tabular}


bone is observed in $\mathbf{3 c}$ and $\mathbf{4 c}$ with the $\mathrm{S} 1-\mathrm{C} 1 \cdots \mathrm{C} 9-\mathrm{S} 9$ torsion and central C1-C10-C5-C6 and C9-C10-C5-C4 ring torsions lower than those seen previously.

The ionic tetranuclear complex $\mathbf{3 d}$ contains two distinct $\mathrm{Rh}-\mathrm{S}$ bond lengths from the terminal and bridging ligands. The terminal ligand has $\mathrm{Rh}-\mathrm{S}$ bond lengths ranging from 2.336(2)-2.383(2) A which are similar to those we have previously observed in 3c. However the bridging ligand shows Rh$\mathrm{S}$ bond lengths in the range of 2.449(2)-2.466(2) A which are similar to lengths observed in $\mathbf{3 b}$. Unlike the other charged complexes presented here the non- $\mathrm{Cp}^{*}$ angles around the metal centre show a wide range $\left[74.67(5)^{\circ}-80.09(5)^{\circ}\right]$. This is likely due to the steric demands of the biphenyl backbone preventing the sulfur atom (S41) from adopting a more idealised position. The aryl-aryl torsion on the terminal ligand is $69.2(9)^{\circ}$ which is similar to that observed for the pro-ligand. ${ }^{37}$ In contrast the aryl-aryl torsion of the bridging ligand is $-28(1)^{\circ}$ as the ligand chelates the two metal centres.

\section{Conclusion}

We have prepared and characterised a series of $\mathrm{Rh}(\mathrm{III})$ and $\operatorname{Ir}(\mathrm{III}) \eta^{5}-\mathrm{Cp}^{*}$ half sandwich complexes by chloride ligand replacement reactions of $\left[\mathrm{Cp}^{*} \mathrm{RhCl}_{2}\right]_{2}$ and $\left[\mathrm{Cp}^{*} \mathrm{IrCl}_{2}\right]_{2}$ with a series of dithiols with aromatic backbones. This work demonstrates the utility and versatility of these sulfur ligands in organometallic complexes. The ligands have shown remarkable variety in the type of complexes formed. A subtle change in the organic backbone (naphthalene to acenaphthene) resulted in a profound difference in the structure of the complex formed. In addition the introduction of rotationally free backbone produced yet another type of structure. Single crystal X-ray diffraction confirmed these three distinct complex classes; such a variety is achieved through the utilisation of $\kappa^{1}$ and $\kappa^{2}$ bonding of the sulfur donor atoms and via chelating and bridging coordination modes of the dithiolate ligands.

\section{Experimental}

\section{General}

Unless otherwise stated all manipulations were performed under an oxygen-free nitrogen atmosphere using standard Schlenk techniques and glassware. Solvents were collected from an MBraun Solvent Purification System or dried and stored according to common procedures. ${ }^{46}\left[\mathrm{Cp}^{*} \mathrm{RhCl}_{2}\right]_{2}$ and $\left[\mathrm{Cp}^{*} \mathrm{IrCl}_{2}\right]_{2}$ were prepared following a literature procedure which is included in the ESI. $\dagger^{38}$ The synthesis of $\left[\mathrm{Cp}^{*} \mathrm{Rh}(o\right.$ $\left.\left.\mathrm{C}_{6} \mathrm{H}_{4} \mathrm{~S}_{2}\right)\right]_{2}$ and $\left[\mathrm{Cp}^{*} \operatorname{Ir}\left(o-\mathrm{C}_{6} \mathrm{H}_{4} \mathrm{~S}_{2}\right)\right]$ using our method based on literature preparation ${ }^{39}$ is reported in the ESI. $\uparrow$ The disulfide precursors were made according to literature methods. ${ }^{34-36}$ Proligands $\mathbf{H}_{2} \mathbf{b}$-d were prepared following a modified literature procedure, ${ }^{37,47} \mathbf{H}_{2}$ a was prepared according to literature. ${ }^{33,48}$ IR and Raman spectra were collected on a Perkin Elmer 2000 NIR/Raman Fourier Transform spectrometer with a dipole pumped NdYAG near-IR excitation laser. ${ }^{1} \mathrm{H}$ and ${ }^{13} \mathrm{C}$ NMR spectra were obtained on either a Bruker Avance III 500 spectrometer or a JEOL GSX Delta 270 with $\delta_{\mathrm{H}} \& \delta_{\mathrm{C}}$ relative to TMS, residual solvent peaks $\left(\mathrm{CDCl}_{3} ; \delta_{\mathrm{H}} 7.26, \delta_{\mathrm{C}} 77.2 \mathrm{ppm}\right)$ were used for calibration. All measurements were performed at $25^{\circ} \mathrm{C}$ with shifts reported in ppm; $p$ t has been used to denote a pseudo triplet. Electrospray (ES+) mass spectra were carried out by the University of St Andrews Mass Spectrometry service and Atmospheric Pressure Chemical Ionisation (APCI+) by the EPSRC National Mass Spectrometry Service, Swansea. Elemental analyses were performed by Stephen Boyer at the London Metropolitan University.

$\left[\mathbf{C p}{ }^{*} \mathbf{R h}\left(\mathbf{C}_{10} \mathbf{H}_{8} \mathbf{S}_{2}\right)\right]_{2}$ (3b). $\left[\mathrm{Cp}^{*} \mathrm{RhCl}_{2}\right]_{2}(100 \mathrm{mg}, 0.16 \mathrm{mmol})$ was added to THF $(25 \mathrm{~mL})$ followed by $\mathbf{H}_{2} \mathbf{b}(100 \mathrm{mg}$, $0.52 \mathrm{mmol}$ ) and the reaction mixture was refluxed for $3 \mathrm{~h}$; during this time a red precipitate formed. The precipitate was collected by filtration and washed with THF then diethyl ether. Purification by column chromatography (silica/ $\mathrm{CH}_{2} \mathrm{Cl}_{2}$ ) resulted in $\mathbf{3 b}$ as a red solid $(111 \mathrm{mg}, 0.12 \mathrm{mmol}, 75 \%)$. Crystals suitable for X-ray work were obtained from $\mathrm{CHCl}_{3}$. Anal. calcd for $\mathrm{C}_{40} \mathrm{H}_{42} \mathrm{Rh}_{2} \mathrm{~S}_{4}\left(856.02 \mathrm{~g} \mathrm{~mol}^{-1}\right)$ : C, 56.07; H, 4.95. Found: C, 55.94; H, 5.01. IR (KBr): $\nu_{\max } / \mathrm{cm}^{-1} 3039 \mathrm{w}\left(\nu_{\mathrm{Ar}-\mathrm{H}}\right)$, $2907 \mathrm{w}\left(\nu_{\mathrm{C}-\mathrm{H}}\right), 1537 \mathrm{~s}, 1377 \mathrm{~m}, 1193 \mathrm{~s}, 1025 \mathrm{w}, 817 \mathrm{~s}, 763 \mathrm{~s}, 538 \mathrm{w}$. Raman (glass capillary): $\nu_{\max } / \mathrm{cm}^{-1} 3040 \mathrm{w}\left(\nu_{\mathrm{Ar}-\mathrm{H}}\right), 2909 \mathrm{w}\left(\nu_{\mathrm{C}-\mathrm{H}}\right)$, $1540 \mathrm{~s}, 1325 \mathrm{~s}, 882 \mathrm{~s}, 548 \mathrm{w}\left(\nu_{\mathrm{C}-\mathrm{S}}\right), 447 \mathrm{~m}, 388 \mathrm{~m} .{ }^{1} \mathrm{H} \quad \mathrm{NMR}$ $\left(500 \mathrm{MHz}, \mathrm{CDCl}_{3}\right): \delta=8.14\left(2 \mathrm{H}, \mathrm{d},{ }^{3} J_{\mathrm{HH}}=6.8 \mathrm{~Hz}, \mathrm{Ar}-\underline{\mathrm{H}}\right), 7.78$ $\left(2 \mathrm{H}, \mathrm{d},{ }^{3} J_{\mathrm{HH}}=7.2 \mathrm{~Hz}, \mathrm{Ar}-\underline{\mathrm{H}}\right), 7.70\left(2 \mathrm{H}, \mathrm{d},{ }^{3} J_{\mathrm{HH}}=7.8 \mathrm{~Hz}, \mathrm{Ar}-\underline{\mathrm{H}}\right)$, $7.50\left(2 \mathrm{H}, \mathrm{d},{ }^{3} J_{\mathrm{HH}}=7.8 \mathrm{~Hz}, \mathrm{Ar}-\underline{\mathrm{H}}\right), 7.17\left(2 \mathrm{H}, p \mathrm{t},{ }^{3} J_{\mathrm{HH}}=7.4 \mathrm{~Hz}\right.$, $\mathrm{Ar}-\underline{\mathrm{H}}), 7.14\left(2 \mathrm{H}, p \mathrm{t},{ }^{3} \mathrm{~J}_{\mathrm{HH}}=7.5 \mathrm{~Hz}, \mathrm{Ar}-\underline{\mathrm{H}}\right), 1.17(30 \mathrm{H}, \mathrm{s}, \mathrm{C}-$ $\left.\mathrm{CH}_{3}\right) \cdot{ }^{13} \mathrm{C}$ NMR $\left(125 \mathrm{MHz}, \mathrm{CDCl}_{3}\right): \delta=141.1\left(\mathrm{C}_{\mathrm{q}}, \mathrm{Ar}-\underline{\mathrm{C}}\right), 136.1$ $\left(\mathrm{C}_{\mathrm{q}}, \mathrm{Ar}-\underline{\mathrm{C}}\right), 135.5\left(\mathrm{C}_{\mathrm{q}}, \mathrm{Ar}-\underline{\mathrm{C}}\right), 132.0(\mathrm{CH}, \mathrm{Ar}-\underline{\mathrm{C}}), 130.5\left(\mathrm{C}_{\mathrm{q}}, \mathrm{Ar}-\underline{\mathrm{C}}\right)$, $129.3(\mathrm{CH}, \mathrm{Ar}-\mathrm{C}), 129.2$ (CH, Ar-C), 124.9 (CH, Ar-C), 124.7 $(\mathrm{CH}, \mathrm{Ar}-\mathrm{C}), 123.3(\mathrm{CH}, \mathrm{Ar}-\underline{\mathrm{C}}), 96.5\left(\mathrm{C}_{\mathrm{q}}, \mathrm{d},{ }^{1} J_{\mathrm{CRh}}=5.7 \mathrm{~Hz}, \underline{\mathrm{C}}-\right.$ $\mathrm{CH}_{3}$ ), $8.0\left(\mathrm{C}-\mathrm{CH}_{3}\right)$. HRMS (APCI+): $\mathrm{m} / z$ Calcd for $\mathrm{C}_{40} \mathrm{H}_{43} \mathrm{~S}_{4} \mathrm{Rh}_{2}$ : 857.0352, found: $857.0359(\mathrm{M}+\mathrm{H}, 25 \%)$; Calcd for $\mathrm{C}_{20} \mathrm{H}_{22} \mathrm{~S}_{2} \mathrm{Rh}: 429.0217$, found $429.0215\left(\frac{1}{2} \mathrm{M}+\mathrm{H}, 100\right)$.

$\left[\mathbf{C p}^{*} \operatorname{Ir}\left(\mathbf{C}_{10} \mathbf{H}_{8} \mathbf{S}_{2}\right)\right]_{2}(\mathbf{4 b})$. This was prepared as per complex $3 \mathbf{b}$ using $\left[\mathrm{Cp}^{*} \mathrm{IrCl}_{2}\right]_{2}(150 \mathrm{mg}, 0.18 \mathrm{mmol})$ and $\mathbf{H}_{2} \mathbf{b}(116 \mathrm{mg}$, $0.60 \mathrm{mmol}$ ) with refluxing for $4 \mathrm{~h}$. $4 \mathrm{~b}$ was obtained as a yellow solid (89 mg, $0.085 \mathrm{mmol}, 46 \%$ ). Crystals suitable for X-ray work were obtained from $\mathrm{CHCl}_{3}$. Anal. calcd for $\mathrm{C}_{40} \mathrm{H}_{42} \mathrm{Ir}_{2} \mathrm{~S}_{4}$ (1035.45 $\mathrm{g} \mathrm{mol}^{-1}$ ): C, 46.40; H, 4.09. Found: C, 46.27; H, 4.14. IR (KBr): $\nu_{\text {max }} / \mathrm{cm}^{-1} 3043 \mathrm{w}\left(\nu_{\mathrm{Ar}-\mathrm{H}}\right), 2909 \mathrm{~m}\left(\nu_{\mathrm{C}-\mathrm{H}}\right), 1538 \mathrm{~s}$, $1196 \mathrm{~m}, 1184 \mathrm{~m}, 814 \mathrm{~s}, 761 \mathrm{~s}, 500 \mathrm{w}$. Raman (glass capillary): $\nu_{\max } / \mathrm{cm}^{-1} 3052 \mathrm{w}\left(\nu_{\mathrm{Ar}-\mathrm{H}}\right), 2912 \mathrm{~m}\left(\nu_{\mathrm{C}-\mathrm{H}}\right), 1540 \mathrm{~s}, 1417 \mathrm{~m}, 1325 \mathrm{~s}$, $1142 \mathrm{~m}, 881 \mathrm{~s}, 548 \mathrm{~m}\left(\nu_{\mathrm{C}-\mathrm{s}}\right), 456 \mathrm{~m}, 391 \mathrm{~m} .{ }^{1} \mathrm{H}$ NMR $(500 \mathrm{MHz}$, $\left.\mathrm{CDCl}_{3}\right): \delta=8.14\left(2 \mathrm{H}, \mathrm{dd},{ }^{3} J_{\mathrm{HH}}=7.2 \mathrm{~Hz},{ }^{4} J_{\mathrm{HH}}=1.2 \mathrm{~Hz}, \mathrm{Ar}-\underline{\mathrm{H}}\right)$, $7.76\left(2 \mathrm{H}, \mathrm{dd},{ }^{3} J_{\mathrm{HH}}=7.2 \mathrm{~Hz},{ }^{4} J_{\mathrm{HH}}=1.2 \mathrm{~Hz}, \mathrm{Ar}-\underline{\mathrm{H}}\right), 7.73(2 \mathrm{H}, \mathrm{d}$, $\left.{ }^{3} J_{\mathrm{HH}}=8.1 \mathrm{~Hz}, \mathrm{Ar}-\underline{\mathrm{H}}\right), 7.50\left(2 \mathrm{H}, \mathrm{d},{ }^{3} J_{\mathrm{HH}}=8.1 \mathrm{~Hz}, \mathrm{Ar}-\underline{\mathrm{H}}\right)$, $7.12\left(2 \mathrm{H}, p \mathrm{t},{ }^{3} \mathrm{~J}_{\mathrm{HH}}=7.6 \mathrm{~Hz}, \mathrm{Ar}-\underline{\mathrm{H}}\right), 7.09\left(2 \mathrm{H}, p \mathrm{t},{ }^{3} J_{\mathrm{HH}}=7.6\right.$ $\mathrm{Hz}, \mathrm{Ar}-\underline{\mathrm{H}}$ ), $1.22\left(30 \mathrm{H}, \mathrm{s}, \mathrm{C}-\mathrm{CH}_{3}\right) .{ }^{13} \mathrm{C} \mathrm{NMR}\left(125 \mathrm{MHz}, \mathrm{CDCl}_{3}\right)$ : $\delta=137.6\left(\mathrm{C}_{\mathrm{q}}, \mathrm{Ar}-\underline{\mathrm{C}}\right), 135.7\left(\mathrm{C}_{\mathrm{q}}, \mathrm{Ar}-\underline{\mathrm{C}}\right), 130.2(\mathrm{CH}, \mathrm{Ar}-\underline{\mathrm{C}})$, $129.2(\mathrm{CH}, \mathrm{Ar}-\mathrm{C}), 128.4(\mathrm{CH}, \mathrm{Ar}-\mathrm{C}), 127.4\left(\mathrm{C}_{\mathrm{q}}, \mathrm{Ar}-\underline{\mathrm{C}}\right), 125.0$ $(\mathrm{CH}, \mathrm{Ar}-\underline{\mathrm{C}}), 124.0(\mathrm{CH}, \mathrm{Ar}-\underline{\mathrm{C}}), 123.5\left(\mathrm{C}_{\mathrm{q}}, \mathrm{Ar}-\underline{\mathrm{C}}\right), 123.3(\mathrm{CH}$, Ar- $\underline{\mathrm{C}}), 91.1\left(\mathrm{C}_{\mathrm{q}}, \underline{\mathrm{C}}-\mathrm{CH}_{3}\right), 7.7\left(\mathrm{C}-\underline{\mathrm{CH}}_{3}\right)$. HRMS (APCI+): $\mathrm{m} / \mathrm{z}$ Calcd for $\mathrm{C}_{40} \mathrm{H}_{43} \mathrm{~S}_{4} \mathrm{Ir}_{2}$ : 1035.1475, found $1035.1479(\mathrm{M}+\mathrm{H}$, 
20\%); Calcd for $\mathrm{C}_{20} \mathrm{H}_{22} \mathrm{~S}_{2} \mathrm{Ir}$ : 519.0792 , found $519.0781\left(\frac{1}{2} \mathrm{M}+\mathrm{H}\right.$, 100).

$\left[\left(\mathbf{C} \mathbf{p}^{*} \mathbf{R h}\right)_{2}\left(\boldsymbol{\mu}^{2}-\mathbf{C l}\right)\left(\mathbf{C}_{12} \mathbf{H}_{10} \mathbf{S}_{2}\right)\right] \mathbf{C l}$ (3c). Method 1: $\left[\mathrm{Cp}^{*} \mathrm{RhCl}_{2}\right]_{2}$ (100 mg, $0.16 \mathrm{mmol}$ ) was added to THF $(25 \mathrm{~mL}$ ) followed by $\mathbf{H}_{2} \mathbf{c}(113 \mathrm{mg}, 0.51 \mathrm{mmol})$ and the reaction refluxed for $2 \mathrm{~h}$. The precipitate was obtained by filtration and added to $\mathrm{CH}_{2} \mathrm{Cl}_{2}$ $(15 \mathrm{~mL})$ then the undissolved solid removed by filtration. Removal of the solvent under vacuum afforded $3 \mathbf{c}$ as a red solid (63 mg, $0.082 \mathrm{mmol}, 52 \%$ ).

Method 2: A MeOH $(25 \mathrm{~mL})$ solution containing $\left[\mathrm{Cp}^{*} \mathrm{RhCl}_{2}\right]_{2}$ (100 mg, $0.16 \mathrm{mmol}), \mathbf{H}_{2} \mathbf{c}(70 \mathrm{mg}, 0.32 \mathrm{mmol})$ and $\mathrm{NaOMe}$ $(17 \mathrm{mg}, 0.32 \mathrm{mmol}$ ) was stirred at room temperature $\mathrm{O} / \mathrm{N}$. The solvent was removed and the crude product purified by column chromatography (silica/ $\mathrm{CH}_{2} \mathrm{Cl}_{2}: \mathrm{MeOH}(9: 1)$ ). 3c was obtained (101 mg, $0.13 \mathrm{mmol}, 83 \%)$. Crystals suitable for X-ray work were obtained from $\mathrm{CH}_{2} \mathrm{Cl}_{2}$ /ether. Anal. calcd for $\mathrm{C}_{32} \mathrm{H}_{38} \mathrm{Cl}_{2} \mathrm{Rh}_{2} \mathrm{~S}_{2}\left(761.99 \mathrm{~g} \mathrm{~mol}^{-1}\right): \mathrm{C}, 50.34 ; \mathrm{H}, 5.01$. Found: $\mathrm{C}$, 50.12; H, 4.71. IR (KBr): $\nu_{\max } / \mathrm{cm}^{-1} 2918 \mathrm{~m}\left(\nu_{\mathrm{C}-\mathrm{H}}\right), 1591 \mathrm{~m}$, 1444s, 1376s, 1353s, 1024s, 733m. Raman (glass capillary): $\nu_{\max } / \mathrm{cm}^{-1} 3048 \mathrm{~W}\left(\nu_{\mathrm{Ar}-\mathrm{H}}\right), 2919 \mathrm{~s}\left(\nu_{\mathrm{C}-\mathrm{H}}\right), 1592 \mathrm{~s}, 1407 \mathrm{~s}, 588 \mathrm{~s}$ $\left(\nu_{\mathrm{C}-\mathrm{S}}\right), 460 \mathrm{~s}, 430 \mathrm{~s}, 416 \mathrm{~s}, 269 \mathrm{w}\left(\nu_{\mathrm{Rh}-\mathrm{Cl}}\right) .{ }^{1} \mathrm{H}$ NMR $(500 \mathrm{MHz}$, $\left.\mathrm{CDCl}_{3}\right): \delta=8.37\left(2 \mathrm{H}, \mathrm{d},{ }^{3} J_{\mathrm{HH}}=7.2 \mathrm{~Hz}, \mathrm{Ar}-\underline{\mathrm{H}}\right), 7.45\left(2 \mathrm{H}, \mathrm{d},{ }^{3} J_{\mathrm{HH}}\right.$ $=7.2 \mathrm{~Hz}, \mathrm{Ar}-\underline{\mathrm{H}}), 3.37\left(4 \mathrm{H}, \mathrm{s}, \mathrm{CH}_{2}-\mathrm{CH}_{2}\right), 1.23\left(30 \mathrm{H}, \mathrm{s}, \mathrm{C}-\mathrm{CH}_{3}\right)$. ${ }^{13} \mathrm{C}$ NMR $\left(125 \mathrm{MHz}, \mathrm{CDCl}_{3}\right): \delta=150.0\left(\mathrm{C}_{\mathrm{q}}, \mathrm{Ar}-\mathrm{C}\right), 139.8\left(\mathrm{C}_{\mathrm{q}}\right.$, Ar-C $), 132.2(\mathrm{CH}, \mathrm{Ar}-\underline{\mathrm{C}}), 128.0\left(\mathrm{C}_{\mathrm{q}}, \mathrm{Ar}-\underline{\mathrm{C}}\right), 124.5\left(\mathrm{C}_{\mathrm{q}}, \mathrm{Ar}-\underline{\mathrm{C}}\right)$, $120.1(\mathrm{CH}, \mathrm{Ar}-\mathrm{C}), 97.0\left(\mathrm{C}_{\mathrm{q}}, \mathrm{d},{ }^{1} J_{\mathrm{CRh}}=7.4 \mathrm{~Hz}, \underline{\mathrm{C}}-\mathrm{CH}_{3}\right), 30.8$ $\left(\mathrm{CH}_{2}-\underline{\mathrm{CH}}_{2}\right), 8.2\left(\mathrm{C}-\mathrm{CH}_{3}\right)$. MS (ES+): $m / z 727.02(\mathrm{M}-\mathrm{Cl}, 100 \%)$.

$\left[\left(\mathbf{C} \mathbf{p}^{*} \mathbf{I r}\right)_{2}\left(\boldsymbol{\mu}^{2}-\mathbf{C l}\right)\left(\mathbf{C}_{12} \mathbf{H}_{10} \mathbf{S}_{2}\right)\right] \mathbf{C l}$ (4c). Method 1: This was prepared as per method 1 complex $3 \mathbf{c}$ using $\left[\mathrm{Cp}^{*} \mathrm{IrCl}_{2}\right]_{2}(200 \mathrm{mg}$, $0.25 \mathrm{mmol}$ ) and $\mathbf{H}_{2} \mathbf{c}(137 \mathrm{mg}, 0.627 \mathrm{mmol})$ with refluxing for $3 \mathrm{~h} .4 \mathrm{c}$ was obtained as a yellow solid ( $5 \mathrm{mg}, 5.3 \mu \mathrm{mol}, 2 \%)$.

Method 2: This was prepared as per method 2 complex 3c using $\quad\left[\mathrm{Cp}^{*} \mathrm{IrCl}_{2}\right]_{2} \quad(150 \mathrm{mg}, \quad 0.18 \mathrm{mmol}), \quad \mathbf{H}_{2} \mathbf{c}(79 \mathrm{mg}$, $0.36 \mathrm{mmol})$ and NaOMe $(20 \mathrm{mg}, 0.36 \mathrm{mmol}) .4 \mathrm{c}$ was obtained (174 mg, $0.18 \mathrm{mmol}, 98 \%$ ). Crystals suitable for X-ray work were obtained from $\mathrm{CH}_{2} \mathrm{Cl}_{2} /$ ether. Anal. calcd for $\mathrm{C}_{32} \mathrm{H}_{38} \mathrm{Cl}_{2} \mathrm{Ir}_{2} \mathrm{~S}_{2}$ (942.10 g mol${ }^{-1}$ ): C, 40.75; H, 4.07. Found: C, 40.67; H, 4.12. IR (KBr): $\nu_{\max } / \mathrm{cm}^{-1} 3132 \mathrm{~m}\left(\nu_{\mathrm{Ar}-\mathrm{H}}\right), 2918 \mathrm{~m}$ $\left(\nu_{\mathrm{C}-\mathrm{H}}\right), 1592 \mathrm{~m}, 1452 \mathrm{~s}, 1355 \mathrm{~s}, 1214 \mathrm{~m}, 1030 \mathrm{~s}, 860 \mathrm{~m}$. Raman (glass capillary): $\nu_{\max } / \mathrm{cm}^{-1} 2920 \mathrm{~s}\left(\nu_{\mathrm{C}-\mathrm{H}}\right), 1593 \mathrm{~m}, 1408 \mathrm{~s}$, $1344 \mathrm{~m}, 584 \mathrm{~m}\left(\nu_{\mathrm{C}-\mathrm{S}}\right), 430 \mathrm{~s} .{ }^{1} \mathrm{H}$ NMR $\left(500 \mathrm{MHz}, \mathrm{CDCl}_{3}\right): \delta=8.27$ $\left(2 \mathrm{H}, \mathrm{d},{ }^{3} J_{\mathrm{HH}}=7.1 \mathrm{~Hz}, \mathrm{Ar}-\underline{\mathrm{H}}\right), 7.31\left(2 \mathrm{H}, \mathrm{d},{ }^{3} J_{\mathrm{HH}}=7.1 \mathrm{~Hz}, \mathrm{Ar}-\underline{\mathrm{H}}\right)$, $3.21\left(4 \mathrm{H}, \mathrm{s}, \mathrm{CH}_{2}-\mathrm{CH}_{2}\right), 1.25\left(30 \mathrm{H}, \mathrm{s}, \mathrm{C}-\mathrm{CH}_{3}\right) .{ }^{13} \mathrm{C} \mathrm{NMR}$ $\left(125 \mathrm{MHz}, \mathrm{CDCl}_{3}\right): \delta=148.7\left(\mathrm{C}_{\mathrm{q}}, \mathrm{Ar}-\underline{\mathrm{C}}\right), 140.0\left(\mathrm{C}_{\mathrm{q}}, \mathrm{Ar}-\underline{\mathrm{C}}\right), 129.3$ $(\mathrm{CH}, \mathrm{Ar}-\underline{\mathrm{C}}), 128.0\left(\mathrm{C}_{\mathrm{q}}, \mathrm{Ar}-\underline{\mathrm{C}}\right), 122.2\left(\mathrm{C}_{\mathrm{q}}, \mathrm{Ar}-\underline{\mathrm{C}}\right), 120.3(\mathrm{CH}$, $\mathrm{Ar}-\underline{\mathrm{C}}), 90.0\left(\mathrm{C}_{\mathrm{q}}, \underline{\mathrm{C}}-\mathrm{CH}_{3}\right), 30.8\left(\underline{\mathrm{CH}}_{2}-\underline{\mathrm{CH}}_{2}\right), 8.0\left(\mathrm{C}^{-} \underline{\mathrm{CH}}_{3}\right)$. HRMS (ES+): $\mathrm{m} / z$ Calcd for $\mathrm{C}_{22} \mathrm{H}_{23} \mathrm{ClS}_{2} \mathrm{Ir}$ : 907.1362, found 907.1316 $(\mathrm{M}-\mathrm{Cl}, 100 \%)$.

$\left[\left(\mathbf{C p}^{*} \mathbf{R h}\right)_{4}\left(\mathbf{C}_{12} \mathbf{H}_{10} \mathbf{S}_{2}\right)_{3}\right] \mathbf{C l}_{2} \quad$ (3d). $\left[\mathrm{Cp}^{*} \mathrm{RhCl}_{2}\right] \quad(150 \quad \mathrm{mg}$, $0.24 \mathrm{mmol})$ was added to THF $(25 \mathrm{~mL})$ followed by $\mathbf{H}_{2} \mathbf{d}$ (169 mg, $0.77 \mathrm{mmol}$ ) and the reaction refluxed for $4 \mathrm{~h}$. The solvent was removed and the crude compound purified by column chromatography (silica/ $\mathrm{CH}_{2} \mathrm{Cl}_{2}$ : EtOH $(9: 1)$ ) to afford 3d as an orange solid (155 mg, $0.096 \mathrm{mmol}, 40 \%)$. Crystals suitable for X-ray work were obtained from $\mathrm{CH}_{2} \mathrm{Cl}_{2} /$ ether. IR (KBr): $\nu_{\max } / \mathrm{cm}^{-1} 3047 \mathrm{w}\left(\nu_{\mathrm{Ar}-\mathrm{H}}\right), 2917 \mathrm{w}\left(\nu_{\mathrm{C}-\mathrm{H}}\right), 1452 \mathrm{~s}, 1376 \mathrm{~m}$, 1021s, 754s, 495w. Raman (glass capillary): $\nu_{\max } / \mathrm{cm}^{-1} 3054 \mathrm{~m}$ $\left(\nu_{\mathrm{Ar}-\mathrm{H}}\right), 2916 \mathrm{~s}\left(\nu_{\mathrm{C}-\mathrm{H}}\right), 1582 \mathrm{~s}, 1426 \mathrm{~m}, 1300 \mathrm{~m}, 1041 \mathrm{~s}, 437 \mathrm{~m}, 415 \mathrm{~s}$. ${ }^{1} \mathrm{H}$ NMR $\left(500 \mathrm{MHz}, \mathrm{CDCl}_{3}\right): \delta=8.32\left(2 \mathrm{H}, \mathrm{dd},{ }^{3} J_{\mathrm{HH}}=7.89,{ }^{4} J_{\mathrm{HH}}\right.$ $=1.24 \mathrm{~Hz}, \mathrm{Ar}-\underline{\mathrm{H}}), 8.07\left(2 \mathrm{H}, \mathrm{dd},{ }^{3} J_{\mathrm{HH}}=7.83,{ }^{4} J_{\mathrm{HH}}=1.24 \mathrm{~Hz}\right.$, Ar- $\underline{\mathrm{H}}), 8.02-7.97(2 \mathrm{H}, \mathrm{m}, \mathrm{Ar}-\underline{\mathrm{H}}), 7.74\left(4 \mathrm{H}, \mathrm{t},{ }^{3} J_{\mathrm{HH}}=8.60 \mathrm{~Hz}\right.$, Ar- $\underline{\mathrm{H}}), 7.53-7.47(4 \mathrm{H}, \mathrm{m}, \mathrm{Ar}-\underline{\mathrm{H}}), 7.46-7.26(10 \mathrm{H}, \mathrm{m}, \mathrm{Ar}-\underline{\mathrm{H}})$, $1.20\left(30 \mathrm{H}, \mathrm{s}, \mathrm{C}-\mathrm{CH}_{3}\right), 1.17\left(30 \mathrm{H}, \mathrm{s}, \mathrm{C}-\mathrm{CH}_{3}\right) .{ }^{13} \mathrm{C} \mathrm{NMR}$ $\left(125 \mathrm{MHz}, \mathrm{CDCl}_{3}\right): \delta=138.5\left(\mathrm{C}_{\mathrm{q}}, \mathrm{Ar}-\underline{\mathrm{C}}\right), 138.4\left(\mathrm{C}_{\mathrm{q}}, \mathrm{Ar}-\underline{\mathrm{C}}\right), 137.4$ $(\mathrm{CH}, \mathrm{Ar}-\underline{\mathrm{C}}), 137.1(\mathrm{CH}, \mathrm{Ar}-\underline{\mathrm{C}}), 136.7(\mathrm{CH}, \mathrm{Ar}-\underline{\mathrm{C}}), 135.9\left(\mathrm{C}_{\mathrm{q}}\right.$, $\left.{ }^{A r}-\underline{C}\right), 132.8(\mathrm{CH}, \mathrm{Ar}-\underline{\mathrm{C}}), 132.7\left(\mathrm{CH}, \mathrm{Ar}^{-} \underline{\mathrm{C}}\right), 131.7\left(\mathrm{CH}, \mathrm{Ar}^{-} \underline{\mathrm{C}}\right)$, $130.4(\mathrm{CH}, \mathrm{Ar}-\mathrm{C}), 128.9(\mathrm{CH}, \mathrm{Ar}-\underline{\mathrm{C}}), 128.5(\mathrm{CH}, \mathrm{Ar}-\mathrm{C}), 128.4$ $(\mathrm{CH}, \mathrm{Ar}-\mathrm{C}), 128.3(\mathrm{CH}, \mathrm{Ar}-\mathrm{C}), 126.3(\mathrm{CH}, \mathrm{Ar}-\mathrm{C}), 126.0(\mathrm{CH}, \mathrm{Ar}-$ C), $125.2\left(\mathrm{C}_{\mathrm{q}}, \mathrm{Ar}-\mathrm{C}\right), 124.8(\mathrm{CH}, \mathrm{Ar}-\underline{\mathrm{C}}), 98.6\left(\mathrm{C}_{\mathrm{q}}, \mathrm{d},{ }^{1} J_{\mathrm{CRh}}=6.7\right.$ $\left.\mathrm{Hz}, \underline{\mathrm{C}}-\mathrm{CH}_{3}\right), 98.4\left(\mathrm{C}_{\mathrm{q}}, \mathrm{d},{ }^{1} J_{\mathrm{CRh}}=6.5 \mathrm{~Hz}, \underline{\mathrm{C}}-\mathrm{CH}_{3}\right), 8.7\left(\mathrm{C}-\underline{\mathrm{CH}}_{3}\right)$, $8.6\left(\mathrm{C}-\mathrm{CH}_{3}\right)$. MS (ES+): $m / z 909.06\left(\mathrm{M}-\mathrm{C}_{32} \mathrm{H}_{37} \mathrm{Rh}_{2} \mathrm{~S}_{2}, 100 \%\right)$, $455.04\left(\mathrm{M}-\mathrm{C}_{54} \mathrm{H}_{60} \mathrm{Rh}_{3} \mathrm{~S}_{4}, 20\right)$.

$\left[\left(\mathbf{C} \mathbf{p}^{*} \mathbf{R h}\right)_{2}\left(\boldsymbol{\mu}^{2}-\mathbf{C l}\right)\left(\mathbf{C}_{\mathbf{1 0}} \mathbf{H}_{8} \mathbf{S}_{2}\right)\right] \mathbf{C l}(\mathbf{5 b})$. A MeOH $(25 \mathrm{~mL})$ solution containing $\left[\mathrm{Cp}^{*} \mathrm{RhCl}_{2}\right]_{2}(150 \mathrm{mg}, 0.24 \mathrm{mmol}), \mathbf{H}_{2} \mathbf{b}(116 \mathrm{mg}$, $0.60 \mathrm{mmol}$ ) and NaOMe (33 $\mathrm{mg}, 0.60 \mathrm{mmol}$ ) was stirred at room temperature $\mathrm{O} / \mathrm{N}$. The solvent was removed and the crude compound purified by column chromatography (silica/ $\mathrm{CH}_{2} \mathrm{Cl}_{2}$ : $\left.\mathrm{MeOH}(9: 1)\right)$ to afford $\mathbf{5 b}$ as a red solid $(102 \mathrm{mg}$, $0.13 \mathrm{mmol}, 58 \%)$. Crystals suitable for X-ray work were obtained from $\mathrm{CH}_{2} \mathrm{Cl}_{2}$ /ether. Anal. calcd for $\mathrm{C}_{30} \mathrm{H}_{36} \mathrm{Cl}_{2} \mathrm{Rh}_{2} \mathrm{~S}_{2}$ (735.97 $\left.\mathrm{g} \mathrm{mol}^{-1}\right)$ : C, 48.91; H, 4.93. Found: C, 48.83; H, 5.04. IR (KBr): $\nu_{\max } / \mathrm{cm}^{-1} 2979 \mathrm{w}\left(\nu_{\mathrm{C}-\mathrm{H}}\right), 2918 \mathrm{~m}\left(\nu_{\mathrm{C}-\mathrm{H}}\right), 1625 \mathrm{~m}, 1493 \mathrm{~s}$, $1450 \mathrm{~s}, 1377 \mathrm{~s}, 1079 \mathrm{~m}, 1023 \mathrm{~s}, 832 \mathrm{~s}, 769 \mathrm{~m}$. Raman (glass capillary): $\nu_{\max } / \mathrm{cm}^{-1} 3065 \mathrm{w}\left(\nu_{\mathrm{Ar}-\mathrm{H}}\right), 2919 \mathrm{~s}\left(\nu_{\mathrm{C}-\mathrm{H}}\right), 1546 \mathrm{~s}, 894 \mathrm{~m}$, $589 \mathrm{~m}\left(\nu_{\mathrm{C}-\mathrm{S}}\right), 460 \mathrm{~m}, 430 \mathrm{~s}, 322 \mathrm{~m}{ }^{1} \mathrm{H}$ NMR $\left(500 \mathrm{MHz}, \mathrm{CDCl}_{3}\right): \delta=$ $8.44\left(2 \mathrm{H}, \mathrm{dd},{ }^{3} J_{\mathrm{HH}}=7.2 \mathrm{~Hz},{ }^{4} J_{\mathrm{HH}}=1.2 \mathrm{~Hz}, \mathrm{Ar}-\underline{\mathrm{H}}\right), 8.13(2 \mathrm{H}$, $\left.\mathrm{dd},{ }^{3} J_{\mathrm{HH}}=8.2 \mathrm{~Hz}, 1.1 \mathrm{~Hz}, \mathrm{Ar}-\underline{\mathrm{H}}\right), 7.59\left(2 \mathrm{H}, \mathrm{dd},{ }^{3} J_{\mathrm{HH}}=8.2,7.2\right.$ $\mathrm{Hz}, \mathrm{Ar}-\underline{\mathrm{H}}), 1.24\left(30 \mathrm{H}, \mathrm{s}, \mathrm{C}-\mathrm{C}_{3}\right) .{ }^{13} \mathrm{C}$ NMR $\left(125 \mathrm{MHz}, \mathrm{CDCl}_{3}\right)$ : $\delta=135.0\left(\mathrm{C}_{\mathrm{q}}, \mathrm{Ar}-\underline{\mathrm{C}}\right), 131.8(\mathrm{CH}, \mathrm{Ar}-\underline{\mathrm{C}}), 131.3(\mathrm{CH}, \mathrm{Ar}-\underline{\mathrm{C}})$, $129.3\left(\mathrm{C}_{\mathrm{q}}, \mathrm{Ar}-\mathrm{C}\right), 128.9\left(\mathrm{C}_{\mathrm{q}}, \mathrm{Ar}-\underline{\mathrm{C}}\right), 125.9(\mathrm{CH}, \mathrm{Ar}-\underline{\mathrm{C}}), 97.3$ $\left(\mathrm{C}_{\mathrm{q}}, \mathrm{d},{ }^{1} \mathrm{~J}_{\mathrm{CRh}}=7.6 \mathrm{~Hz}, \underline{\mathrm{C}}-\mathrm{CH}_{3}\right), 8.3\left(\mathrm{C}^{-} \underline{\mathrm{CH}}_{3}\right) . \mathrm{MS}(\mathrm{ES}+): \mathrm{m} / \mathrm{z}$ $701.00(\mathrm{M}-\mathrm{Cl}, 100 \%)$.

$\left[\left(\mathbf{C p}^{*} \mathbf{I r}\right)_{2}\left(\boldsymbol{\mu}^{2}-\mathbf{C l}\right)\left(\mathbf{C}_{10} \mathbf{H}_{8} \mathbf{S}_{2}\right)\right] \mathbf{C l}(\mathbf{6 b})$. A MeOH $(25 \mathrm{~mL})$ solution containing $\left[\mathrm{Cp}^{*} \mathrm{IrCl}_{2}\right]_{2}(150 \mathrm{mg}, 0.18 \mathrm{mmol}), \mathbf{H}_{2} \mathbf{b}(91 \mathrm{mg}$, $0.47 \mathrm{mmol}$ ) and $\mathrm{NaOMe}(26 \mathrm{mg}, 0.47 \mathrm{mmol}$ ) was stirred at room temperature $\mathrm{O} / \mathrm{N}$. The solvent was removed and the crude product purified by column chromatography (silica/ $\left.\mathrm{CH}_{2} \mathrm{Cl}_{2}: \mathrm{MeOH}(9: 1)\right)$. 6b was obtained as a red/orange solid (124 mg, $0.13 \mathrm{mmol}, 75 \%$ ). Crystals suitable for X-ray work were obtained from $\mathrm{CH}_{2} \mathrm{Cl}_{2}$ /ether. Anal. calcd for $\mathrm{C}_{30} \mathrm{H}_{36} \mathrm{Cl}_{2} \mathrm{Ir}_{2} \mathrm{~S}_{2}\left(916.08 \mathrm{~g} \mathrm{~mol}^{-1}\right): \mathrm{C}, 39.30 ; \mathrm{H}, 3.96$. Found: C, $39.35 ; \mathrm{H}, 4.08$. IR (KBr): $\nu_{\max } / \mathrm{cm}^{-1} 2978 \mathrm{w}\left(\nu_{\mathrm{C}-\mathrm{H}}\right), 2918 \mathrm{~m}\left(\nu_{\mathrm{C}-\mathrm{H}}\right)$, $1626 \mathrm{~m}, 1490 \mathrm{~m}, 1452 \mathrm{~s}, 1381 \mathrm{~s}, 1030 \mathrm{~s}, 831 \mathrm{~s}$, 768s. Raman (glass capillary): $\nu_{\max } / \mathrm{cm}^{-1} 3056 \mathrm{w}\left(\nu_{\mathrm{Ar}-\mathrm{H}}\right), 2921 \mathrm{~s}\left(\nu_{\mathrm{C}-\mathrm{H}}\right), 1547 \mathrm{~s}$, $1426 \mathrm{~m}, 893 \mathrm{~s}, 588 \mathrm{~m}\left(\nu_{\mathrm{C}-\mathrm{S}}\right), 549 \mathrm{~m}, 443 \mathrm{~s}, 425 \mathrm{~s} .{ }^{1} \mathrm{H} \quad \mathrm{NMR}$ $\left(400 \mathrm{MHz}, \mathrm{CDCl}_{3}\right): \delta=8.39\left(2 \mathrm{H}, \mathrm{dd},{ }^{3} J_{\mathrm{HH}}=7.2 \mathrm{~Hz},{ }^{4} J_{\mathrm{HH}}=1.2\right.$ $\mathrm{Hz}, \mathrm{Ar}-\underline{\mathrm{H}}), 8.11\left(2 \mathrm{H}, \mathrm{dd},{ }^{3} J_{\mathrm{HH}}=8.2 \mathrm{~Hz},{ }^{4} J_{\mathrm{HH}}=1.1 \mathrm{~Hz}, \mathrm{Ar}-\underline{\mathrm{H}}\right)$, $7.50\left(2 \overrightarrow{\mathrm{H}}, \mathrm{dd},{ }^{3} J_{\mathrm{HH}}=8.2,7.2 \mathrm{~Hz}, \mathrm{Ar}-\underline{\mathrm{H}}\right), 1.29\left(30 \mathrm{H}, \mathrm{s}, \mathrm{C}-\mathrm{CH}_{3}\right)$. ${ }^{13} \mathrm{C}$ NMR $\left(125 \mathrm{MHz}, \mathrm{CDCl}_{3}\right): \delta=135.2\left(\mathrm{C}_{\mathrm{q}}, \mathrm{Ar}-\underline{\mathrm{C}}\right), 130.6(\mathrm{CH}$, Ar- $\mathrm{C}), 129.5\left(\mathrm{C}_{\mathrm{q}}, \mathrm{Ar}-\mathrm{C}\right), 128.6(\mathrm{CH}, \mathrm{Ar}-\underline{\mathrm{C}}), 126.4(\mathrm{CH}, \mathrm{Ar}-\mathrm{C})$, $90.3\left(\mathrm{C}_{\mathrm{q}}, \underline{\mathrm{C}}-\mathrm{CH}_{3}\right), 8.1\left(\mathrm{C}-\underline{\mathrm{CH}}_{3}\right) \mathrm{MS}(\mathrm{ES}+): \mathrm{m} / z 880.99(\mathrm{M}-\mathrm{Cl}$, $100 \%)$. 
Table 3 Crystallographic data for $3 b-d$ and $5 b$

\begin{tabular}{|c|c|c|c|}
\hline & $3 \mathbf{b}$ & $3 c$ & $3 d$ \\
\hline $\begin{array}{l}\text { Empirical } \\
\text { formula }\end{array}$ & $\mathrm{C}_{40} \mathrm{H}_{42} \mathrm{Rh}_{2} \mathrm{~S}_{2}$ & $\mathrm{C}_{32} \mathrm{H}_{40} \mathrm{Cl}_{2} \mathrm{ORh}_{2} \mathrm{~S}_{2}$ & $\mathrm{C}_{78} \mathrm{H}_{88} \mathrm{Cl}_{6} \mathrm{Rh}_{4} \mathrm{~S}_{6}$ \\
\hline$M$ & 856.82 & 781.50 & 1842.25 \\
\hline Crystal system & Monoclinic & Monoclinic & Orthorhombic \\
\hline Space group & $P 2(1) / n$ & $P 2(1) / c$ & $F d d 2$ \\
\hline$a[\AA]$ & $9.912(4)$ & $13.9932(11)$ & $29.217(4)$ \\
\hline$b[\AA]$ & $16.351(7)$ & $13.8243(10)$ & $44.750(7)$ \\
\hline$c[\AA]$ & $10.915(5)$ & $16.3045(11)$ & $11.2618(17)$ \\
\hline$\left.\alpha^{\circ}{ }^{\circ}\right]$ & 90 & 90 & 90 \\
\hline$\beta\left[{ }^{\circ}\right]$ & $90.662(12)$ & $101.8010(18)$ & 90 \\
\hline$\gamma[0]$ & 90 & 90 & 90 \\
\hline$V\left[\AA^{3}\right]$ & 1768.9(13) & $3087.4(4)$ & $14724(4)$ \\
\hline$Z$ & 2 & 4 & 8 \\
\hline$\rho_{\text {calcd }}\left[\mathrm{g} \mathrm{cm}^{-3}\right]$ & 1.609 & 1.681 & 1.662 \\
\hline$\mu\left[\mathrm{cm}^{-1}\right]$ & 11.957 & 13.999 & 13.109 \\
\hline Measured refln. & 12656 & 37059 & 16519 \\
\hline Unique refln. & 3278 & 5682 & 6472 \\
\hline$R[I>2 \sigma(I)]$ & 0.0665 & 0.0200 & 0.0299 \\
\hline $\mathrm{w} R$ & 0.1653 & 0.0563 & 0.0866 \\
\hline
\end{tabular}

Table 4 Crystallographic data for $4 b$ and $4 c$

\begin{tabular}{|c|c|c|}
\hline & $4 b$ & $4 c$ \\
\hline Empirical formula & $\mathrm{C}_{40} \mathrm{H}_{42} \mathrm{Ir}_{2} \mathrm{~S}_{2}$ & $\mathrm{C}_{32} \mathrm{H}_{40} \mathrm{Cl}_{2} \mathrm{Ir}_{2} \mathrm{OS}_{2}$ \\
\hline$M$ & 1035.45 & 960.13 \\
\hline Crystal system & Monoclinic & Monoclinic \\
\hline Space group & $P 2(1) / n$ & $P 2(1) / c$ \\
\hline$a[\AA]$ & $9.8117(9)$ & $14.1227(16)$ \\
\hline$b[\AA]$ & $16.2184(13)$ & $13.8101(14)$ \\
\hline$c[\AA]$ & $10.8329(8)$ & $16.3080(18)$ \\
\hline$\alpha[\circ]$ & 90 & 90 \\
\hline$\beta[0]$ & $90.330(6)$ & $101.803(2)$ \\
\hline$\gamma[0]$ & 90 & 90 \\
\hline$V\left[\AA^{3}\right]$ & $1723.8(2)$ & $3113.4(6)$ \\
\hline$Z^{2}$ & 2 & 4 \\
\hline$\rho_{\text {calcd }}\left[\mathrm{g} \mathrm{cm}^{-3}\right]$ & 1.995 & 2.048 \\
\hline$\mu\left[\mathrm{cm}^{-1}\right]$ & 80.054 & 88.943 \\
\hline Measured refln & 12983 & 41759 \\
\hline Unique refln. & 3030 & 5686 \\
\hline$R[I>2 \sigma(I)]$ & 0.0149 & 0.0171 \\
\hline $\mathrm{w} R$ & 0.0334 & 0.0378 \\
\hline
\end{tabular}

\section{Crystal structure analysis}

Tables 3 and 4 list the details of data collections and refinements. Data for 3c was collected using a Rigaku FRX (Mo-K, confocal optic) equipped with a Dectris P200 detector at $-100{ }^{\circ} \mathrm{C}$; for $4 \mathrm{~b}$ using a Rigaku Saturn70 at $-148{ }^{\circ} \mathrm{C}$ and for 3b, 3d, 4c, 5b and 6b using a Rigaku FRX (Mo-K, confocal optic) equipped with a Dectris $\mathrm{P} 200$ detector at $-180{ }^{\circ} \mathrm{C}$. Intensities were corrected for Lorentz polarization, and absorption. Structures were solved by direct methods and refined by fullmatrix least-squares against $F^{2}$ (SHELXL). ${ }^{49}$ Hydrogen atoms were assigned riding isotropic displacement parameters and constrained to idealised geometries. Non-hydrogen atoms were refined anisotropically. In the structures of $\mathbf{5 b}$ and $\mathbf{6 b}$ there is disorder within the $\mathrm{Cp}^{*}$ and solvent molecules. Numerous crystallisations were attempted without success, this data represents the best obtained and is used to confirm the connectivity of the complexes only. CCDC no. 1410515-1410521.

\section{References}

1 J. A. McCleverty, N. Spencer, N. A. Bailey and S. L. Shackleton, J. Chem. Soc., Dalton Trans., 1980, 19391944.

2 J. A. McCleverty, N. J. Morrison, N. Spencer, C. C. Ashworth, N. A. Bailey, M. R. Johnson, J. M. A. Smith, B. A. Tabbiner and C. R. Taylor, J. Chem. Soc., Dalton Trans., 1980, 1945-1957.

3 J. R. Phillips, J. C. Poat, A. M. Z. Slawin, D. J. Williams, P. T. Wood and J. D. Woollins, J. Chem. Soc., Dalton Trans., 1995, 2369-2375.

4 A. M. Bond and R. L. Martin, Coord. Chem. Rev., 1984, 54, 23-98.

5 R. Eisenberg, in Prog. Inorg. Chem, John Wiley \& Sons, Inc, 2007, pp. 295-369.

6 F. Tuna, C. A. Smith, M. Bodensteiner, L. Ungur, L. F. Chibotaru, E. J. L. McInnes, R. E. P. Winpenny, D. Collison and R. A. Layfield, Angew. Chem., Int. Ed., 2012, 51, 6976-6980.

7 C.-L. Zhou, Z.-M. Wang, B.-W. Wang and S. Gao, Polyhedron, 2011, 30, 3279-3283.

8 J. D. Woollins, in Biological Interactions of Sulfur Compounds, ed. S. C. Mitchell, Taylor \& Francis, London, 1996, pp. 1-19.

9 B. K. Teo, F. Wudl, J. H. Marshall and A. Kruger, J. Am. Chem. Soc., 1977, 99, 2349-2350.

10 B. K. Teo, F. Wudl, J. J. Hauser and A. Kruger, J. Am. Chem. Soc., 1977, 99, 4862-4863.

11 B. K. Teo and P. A. Snyder-Robinson, Inorg. Chem., 1978, 17, 3489-3497.

12 B. K. Teo and P. A. Snyder-Robinson, Inorg. Chem., 1979, 18, 1490-1495.

13 B. K. Teo and P. A. Snyder-Robinson, J. Chem. Soc., Chem. Commun., 1979, 255-256.

14 B. K. Teo and P. A. Snyder-Robinson, Inorg. Chem., 1981, 20, 4235-4239.

15 B. K. Teo, V. Bakirtzis and P. A. Snyder-Robinson, J. Am. Chem. Soc., 1983, 105, 6330-6332.

16 B. K. Teo and P. A. Snyder-Robinson, Inorg. Chem., 1984, 23, 32-39.

17 W. P. Bosman and H. G. M. van der Linden, J. Chem. Soc., Chem. Commun., 1977, 714-715.

18 M. Tesmer and H. Vahrenkamp, Eur. J. Inorg. Chem., 2001, 1183-1188.

19 C. Claver, S. Castillon, N. Ruiz, G. Delogu, D. Fabbri and S. Gladiali, J. Chem. Soc., Chem. Commun., 1993, 1833-1834. 20 N. Ruiz, A. Aaliti, J. Forniés-Cámer, A. Ruiz, C. Claver, C. J. Cardin, D. Fabbri and S. Gladiali, J. Organomet. Chem., 1997, 545-546, 79-87. 
21 N. Ruiz, S. Castillon, A. Ruiz, C. Claver, A. Aaliti, A. AlvarezLarena, J. F. Piniella and G. Germain, J. Chem. Soc., Dalton Trans., 1996, 969-973.

22 N. Ruiz, I. del Río, J. L. Jiménez, C. Claver, J. ForniésCámer, C. C. J. Cardin and S. Gladiali, J. Mol. Catal. A: Chem., 1999, 143, 171-180.

23 R. J. Wright, C. Lim and T. D. Tilley, Chem. - Eur. J., 2009, 15, 8518-8525.

24 A. P. S. Samuel, D. T. Co, C. L. Stern and M. R. Wasielewski, J. Am. Chem. Soc., 2010, 132, 8813-8815.

25 P. Li, S. Amirjalayer, F. Hartl, M. Lutz, B. d. Bruin, R. Becker, S. Woutersen and J. N. H. Reek, Inorg. Chem., 2014, 53, 5373-5383.

26 J. Ballmann, S. Dechert, S. Demeshko and F. Meyer, Eur. J. Inorg. Chem., 2009, 3219-3225.

27 K. Charreteur, M. Kdider, J.-F. Capon, F. Gloaguen, Y. F. Pétillon, P. Schollhammer and J. Talarmin, Inorg. Chem., 2010, 49, 2496-2501.

28 A. Albers, S. Demeshko, S. Dechert, C. T. Saouma, J. M. Mayer and F. Meyer, J. Am. Chem. Soc., 2014, 136, 3946-3954.

29 C. Topf, U. Monkowius and G. Knör, Inorg. Chem. Commun., 2012, 21, 147-150.

30 M. R. Malachowski, M. Adams, N. Elia, A. L. Rheingold and R. S. Kelly, J. Chem. Soc., Dalton Trans., 1999, 21772182.

31 R. L. McNaughton, A. A. Tipton, N. D. Rubie, R. R. Conry and M. L. Kirk, Inorg. Chem., 2000, 39, 5697-5706.

32 R. Conry and A. A. Tipton, J. Biol. Inorg. Chem., 2001, 6, 359-366.

33 J. Zhao, Z. Wei, X. Zeng and X. Liu, Dalton Trans., 2012, 41, 11125-11133.

34 A. J. Ashe, J. W. Kampf and P. M. Savla, Heteroat. Chem., 1994, 5, 113-119.
35 C. G. M. Benson, C. M. Schofield, R. A. M. Randall, L. Wakefield, F. R. Knight, A. M. Z. Slawin and J. D. Woollins, Eur. J. Inorg. Chem., 2013, 427-437.

36 S. Cossu, G. Delogu, D. Fabbri and P. Maglioli, Org. Prep. Proced. Int., 1991, 23, 455-457.

37 P. S. Nejman, B. Morton-Fernandez, N. Black, D. B. Cordes, A. M. Z. Slawin, P. Kilian and J. D. Woollins, J. Organomet. Chem., 2015, 776, 7-16.

38 C. White, A. Yates and P. M. Maitlis, Inorg. Synth., 1992, 29, 228-234.

39 R. Xi, M. Abe, T. Suzuki, T. Nishioka and K. Isobe, J. Organomet. Chem., 1997, 549, 117-125.

40 M. Nomura, E. Tsukano, C. Fujita-Takayama, T. Sugiyama and M. Kajitani, J. Organomet. Chem., 2009, 694, 31163124.

41 J.-J. Liu, Y.-J. Lin and G.-X. Jin, Dalton Trans., 2015, 44, 10281-10288.

42 F. Takagi, H. Seino, M. Hidai and Y. Mizobe, J. Chem. Soc., Dalton Trans., 2002, 3603-3610.

43 Z.-J. Yao, B. Xu, X.-K. Huo and G.-X. Jin, J. Organomet. Chem., 2013, 747, 85-89.

44 M. R. Churchill, S. A. Julis and F. J. Rotella, Inorg. Chem., 1977, 16, 1137-1141.

45 M. R. Churchill and S. A. Julis, Inorg. Chem., 1977, 16, 1488-1494.

46 W. L. F. Armarego and C. L. L. Chai, Purification of Laboratory Chemicals, Butterworth-Heinemann, Oxford, 6th edn, 2009.

47 K. Yui, Y. Aso, T. Otsubo and F. Ogura, Bull. Chem. Soc. Jpn., 1988, 61, 953-959.

48 E. Block, V. Eswarakrishnan, M. Gernon, G. Ofori-Okai, C. Saha, K. Tang and J. Zubieta, J. Am. Chem. Soc., 1989, 111, 658-665.

49 G. Sheldrick, Acta Crystallogr., Sect. A: Fundam. Crystallogr., 2008, 64, 112-122. 